\title{
Response of cocoa trees (Theobroma cacao) to a 13-month desiccation period in Sulawesi, Indonesia
}

\author{
G. Moser • C. Leuschner - D. Hertel · D. Hölscher • \\ M. Köhler • D. Leitner • B. Michalzik • \\ E. Prihastanti $\cdot$ S. Tjitrosemito $\cdot$ L. Schwendenmann
}

Received: 11 February 2009/ Accepted: 3 April 2010/Published online: 23 April 2010

(C) The Author(s) 2010. This article is published with open access at Springerlink.com

\begin{abstract}
In South-east Asia, ENSO-related droughts represent irregularly occurring hazards for agroforestry systems containing cocoa which are predicted to increase in severity with expected climate warming. To characterize the drought response of mature cocoa trees, we conducted the Sulawesi Throughfall Displacement Experiment in a shaded (Gliricidia sepium) cocoa agroforestry system in Central Sulawesi, Indonesia. Three large sub-canopy roofs were installed to reduce throughfall by about $80 \%$ over a 13 -month period to test the hypotheses that (i) cocoa trees are sensitive to drought due to their shallow fine root system, and (ii) bean yield is more sensitive to drought
\end{abstract}

G. Moser · C. Leuschner ( $₫)$ · D. Hertel

Plant Ecology, Albrecht von Haller Institute for Plant

Sciences, University of Göttingen, Untere Karspüle 2,

37073 Göttingen, Germany

e-mail: cleusch@gwdg.de

D. Hölscher · M. Köhler

Department of Tropical Silviculture and Forest Ecology,

Burckhardt Institute, University of Göttingen,

Büsgenweg 1, 37077 Göttingen, Germany

D. Leitner

Department of Landscape Ecology, Institute of

Geography, University of Göttingen, Goldschmidtstr. 5,

37077 Göttingen, Germany

\section{B. Michalzik}

Department of Soil Sciences, Institute of Geography, University of Jena, Löbdergraben 32, 07743 Jena,

Germany than leaf or stem growth. As $83 \%$ of fine root (diameter $<2 \mathrm{~mm}$ ) and $86 \%$ of coarse root biomass $(>2 \mathrm{~mm}$ ) was located in the upper $40 \mathrm{~cm}$ of the soil, the cocoa trees examined had a very shallow root system. Cocoa and Gliricidia differed in their vertical rooting patterns, thereby reducing competition for water. Despite being exposed for several months to soil water contents close to the conventional wilting point, cocoa trees showed no significant decreases in leaf biomass, stem and branch wood production or fine root biomass. Possible causes are active osmotic adjustment in roots, mitigation of drought stress by shading from Gliricidia or other factors. By contrast, production of cocoa beans

\footnotetext{
E. Prihastanti

Faculty of Mathematics and Natural Sciences,

Diponegoro University, Semarang, Indonesia

S. Tjitrosemito

Faculty of Biology, Bogor Agricultural University,

Jalan Padjajaran, Bogor 16144, Indonesia

L. Schwendenmann

School of Environment, The University of Auckland, PB 92019, Auckland 1142, New Zealand
} 
was significantly reduced in the roof plots, supporting reports of substantial reductions in bean yields during ENSO-related drought events in the region. We conclude that cocoa possesses traits related to drought tolerance which enable it to maintain biomass production during extended dry periods, whereas bean yield appears to be particularly drought sensitive.

Keywords Climate change Cocoa yield . ENSO - Fine roots - Gliricidia sepium .

Leaf biomass - Litter fall - LAI .

Root water potential $\cdot$ Theobroma cacao

\section{Introduction}

Cocao (Theobroma cocao L.), one of the world's most important perennial crops, is primarily used for chocolate production, with an estimated global output of $3.5 \mathrm{~m}$ t of beans being produced in 2006 (ICCO 2007). The area of cocao plantations has increased greatly during the last decade in Indonesia, now the largest cocoa producer in South-east Asia, following the decline in production in Malaysia 20 years ago. Cocoa is cultivated in Indonesia and elsewhere using three different cropping systems, i.e. (i) traditionally under the shade of selectively thinned forest, (ii) under planted shade trees such as Gliricidia sepium or Cocos nucifera, and (iii), increasingly, under unshaded conditions. In some of the Outer Islands of Indonesia, cocoa is currently the most important cash crop, having replaced cultivation of paddy rice for subsistence purposes and fostering the conversion of forest to arable land.

Droughts related to El Niño Southern Oscillation (ENSO) events represent irregularly occurring hazards to intensive cocoa cultivation in Borneo, Sulawesi and other regions of South-east Asia, and are predicted to increase in severity with expected climate warming in the equatorial region (Timmermann et al. 1999; Sheffield and Woods 2008). A recent socioeconomic assessment of the consequences of ENSO-related droughts on cocoa production in Central Sulawesi revealed that bean yield may be reduced in ENSO years to $62 \%$ of its normal level (Keil et al. 2008).

As cocoa is cultivated in South-east Asia not only in humid to perhumid regions, but increasingly in semi-humid climates with an annual rainfall $<1200 \mathrm{~mm}$ and a marked dry season (Cadima
Zevallos 1970; Leite et al. 1980; Beer 1987), the drought response of cocoa and its tolerance of extended rainless periods is of major interest for farmers and the chocolate industry. Moreover, the shift from shaded to unshaded cropping of cocoa in many parts of South-east Asia is likely to increase its exposure to drought as radiation load and atmospheric saturation deficit are typically higher in unshaded systems.

Despite intensive reviews of their ecophysiology (de Almeida and Valle 2007; Schroth et al. 2008), little is known concerning the drought tolerance and adaptation strategies of mature Theobroma cocoa trees because most studies have focussed on seedlings. Several investigations have produced evidence of a vapour pressure deficit (vpd)-sensitive stomatal regulation in cocao leaves (Sena Gomes et al. 1987; Willson 1999), but reduced water use efficiency at high vpd (Sena Gomes et al. 1987), which is likely to induce tissue water deficits under conditions of limited soil water supply. Other authors found evidence for active osmotic adjustment in Theobroma which could increase its drought resistance (de Almeida and Valle 2007). However, it is unclear whether the results can be extrapolated to adult trees in the field.

To characterise the drought sensitivity of adult cocoa trees and identify soil moisture thresholds under field conditions, a replicated drought experiment was conducted in a shaded cocoa agroforestry system in Central Sulawesi, Indonesia, a region where cocoa is extensively cultivated. Three large sub-canopy roofs reduced throughfall by up to $80 \%$ during the 13-month experimental period and allowed effects on productivity, biomass partitioning, and cocoa bean yield to be monitored as a function of soil moisture relative to adjacent control plots. This investigation focussed on the drought response of the belowground compartment (fine, coarse, large roots) and included both cocoa and the most common shade tree (the legume Gliricidia sepium H.B. \& K.). We tested the hypotheses that: (i) cocoa trees are sensitive to drought due to their shallow fine root system; and (ii) bean yield is more sensitive to drought than leaf or stem growth. Previous studies suggested that an extended experimental drought period would cause the death of parts of the fine root system and lead to pre-senescent leaf shedding. 


\section{Materials and methods}

Study site

The cocoa agroforest examined was located close to the village of Marena in the Kulawi Valley, Bolabapu District, Central Sulawesi, Indonesia, $3 \mathrm{~km}$ from the western border of Lore Lindu National Park, a large area of pre-montane to montane rainforest (UTM coordinates: $51 \mathrm{M}, 0168354,9828202)$. Cocoa saplings were planted in December 2000 on former rice and maize fields, together with young plants of the woody legume Gliricidia sepium and a limited number of coconut palms (Cocos nucifera L.) as shade trees. When the study began in September 2006, the cocoa and shade trees were ca. 6-years-old and 5.4 to 8-11 m in height. With ca. 1,000 cocoa trees and 300 shade trees $\mathrm{ha}^{-1}$, the plantation was representative of a common agroforestry system in the region.
The plantation was located $585 \mathrm{~m}$ a.s.l. on a midslope Cambisol $\left(8-11^{\circ}\right.$ inclination) over $30 \mathrm{~m}$ above the nearest main river. The soil consisted mainly of sand (ca. 60\%) and silt (20-30\%) with intermediate layers of gravel; clay content decreased with soil depth, while the sand content increased. Gravel content (grain size $>2 \mathrm{~mm}$ ) was $13 \%$ at depths of $0-50 \mathrm{~cm}$ and $30-33 \%$ at $50-200 \mathrm{~cm} . \mathrm{pH}(\mathrm{KCl})$ ranged between 3.8 and 4.7 .

The study area has a hot perhumid climate with no distinct dry season. Between 2002 and 2006, annual mean temperature at Gimpu meteorological station ( $5 \mathrm{~km}$ south of Marena at $417 \mathrm{~m}$ a.s.l.) was $25.5^{\circ} \mathrm{C}$ and annual mean precipitation was $2,092 \mathrm{~mm}$ (Fig. 1). Mean monthly rainfall exceeded $100 \mathrm{~mm}$ for all months except July, when an average of ca. $80 \mathrm{~mm}$ was recorded (Kreilein, Oltchev and Gravenhorst, pers. comm.). Climatic measurements above the tree canopies at the Marena plantation between
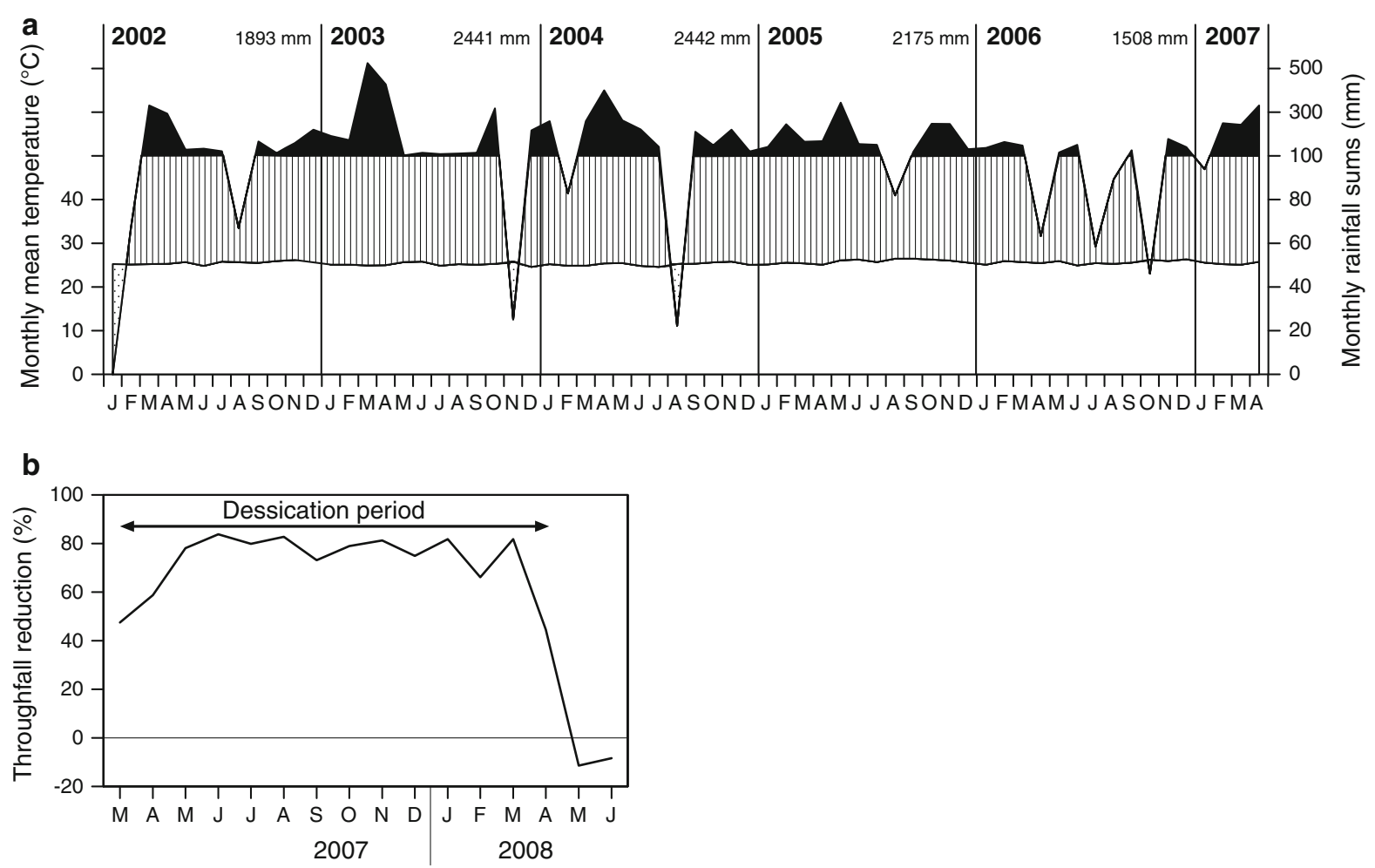

Fig. 1 a Climatogram showing monthly mean air temperature (lower line), monthly rainfall (upper line) and annual rainfall between January 2002 and April 2007 at Gimpu village, Kulawi Valley, Central Sulawesi, ca. $5 \mathrm{~km}$ south of the Marena study site. Stippled areas, vertical lines and solid black areas represent dry, moist and very moist periods. b Reduction in throughfall in the 'roof' treatment relative to control plots between March 2007 and June 2008; the roofs were closed between March 1, 2007 and April 10, 2008 
February 2007 and January 2008 gave an annual mean temperature of $24.4^{\circ} \mathrm{C}$ and an annual rainfall of $2,844 \mathrm{~mm}$. Daily mean relative air humidity was $82 \%$ and the lowest daily mean was $69 \%$.

Management of the plantation during the first 6 years included application of insecticides at 34 month intervals and $\mathrm{N}, \mathrm{P}, \mathrm{K}$ fertilizer annually. The herbaceous layer was mowed at 3-4 month intervals and the cocoa trees were regularly pruned during the first 6 years; this included the cutting of small twigs and branches by local farmers. The number of shade trees was higher during the first 4 years after planting but subsequently was reduced to ca. $300 \mathrm{ha}^{-1}$. Fertilizer and insecticide applications ceased after measurements began in September 2006 but mowing continued at 3-4 monthly intervals. The trees were pruned again in July and November 2007.

\section{Throughfall displacement}

In an area of the plantation with a homogeneous inclination and a typical cocoa and shade tree density, a rectangular area $(80 \mathrm{~m} \times 105 \mathrm{~m})$ was demarcated and subdivided to give six $40 \mathrm{~m} \times 35 \mathrm{~m}$ plots. All measurements were conducted in the central area $(30 \mathrm{~m} \times 25 \mathrm{~m})$ of each plot, surrounded by a $5 \mathrm{~m}$ wide buffer zone to exclude edge effects (Fig. 2). Plots 2, 3 and 6 were randomly selected as roof plots, while the remaining plots served as controls $(1,4,5)$. Between September 2006 and February 2007, belowcanopy roofs were erected in plots 2,3 and 6 (each $40 \mathrm{~m} \times 35 \mathrm{~m}$; Fig. 1a, b) to simulate an extended drought period such as occurs irregularly during moderate or severe ENSO events in parts of Indonesia; these remained in place for 13 months between March

Fig. 2 Photographs taken from a above and b below the 'roof', and (c) schematic representation of the agroforestry system, roof and trenches. a, b $1.2 \mathrm{~m}$ tall bamboo frames covered with light polyethylene sheets were constructed in all 'roof' plots; water was channelled from the roofs to wooden gutters outside the plots. Gaps in the roof resulting from the use of large standard frames $(5 \mathrm{~m} \times 0.5 \mathrm{~m})$ were closed by inserting smaller frames around the trunks of trees. $\mathbf{c}$ Trenches lined with plastic sheet $(40 \mathrm{~cm}$ deep $\times 20 \mathrm{~cm}$ wide $)$ were dug around all plots to exclude lateral water flow and sever the dense mat of fine roots in the surface soil. Trees in the $5 \mathrm{~m}$ boundary zone around all plots were excluded from measurements to avoid edge effects induced by root damage or interactions with adjacent plots. Trees are shown in one roof plot but are omitted from the others
1, 2007 and April 10, 2008. Frames $(5 \mathrm{~m} \times 0.5 \mathrm{~m})$ constructed from bamboo poles and covered by a transparent UV-insensitive polyethylene sheet were placed ca. $1.2 \mathrm{~m}$ above the ground to channel throughfall downhill using the natural inclination of the terrain (Fig. 2). Throughfall captured by the roof was allowed to infiltrate into the soil more than $3 \mathrm{~m}$ beyond the
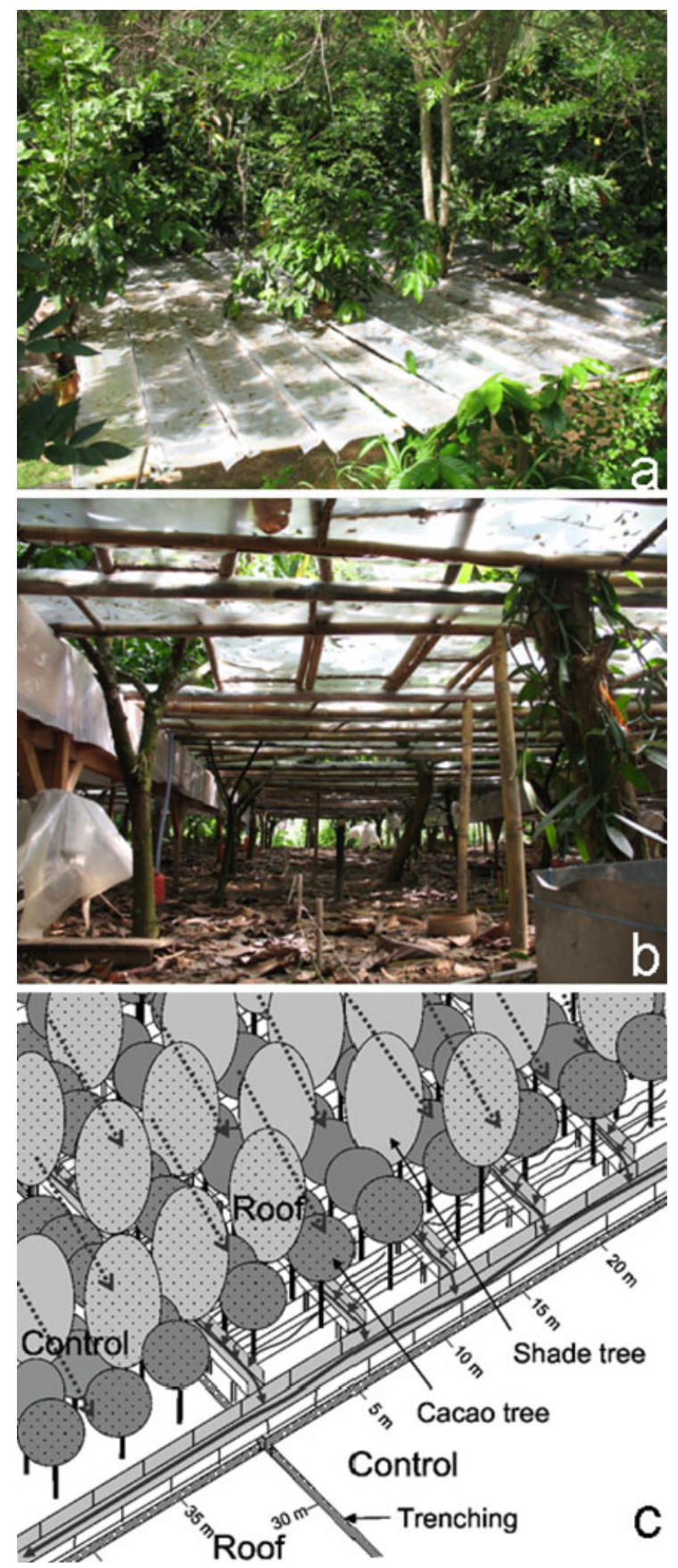
boundary of the study site, in one case more than $20 \mathrm{~m}$ distant. Gaps in the roofs surrounding the stems of cocoa and shade trees were closed using smaller frames that fitted into the openings. Stemflow was not captured. The throughfall reduction was calculated using throughfall data from nine gutters $(4 \mathrm{~m} \times$ $0.2 \mathrm{~m}$ ) in the control plots, and nine gutters above and nine below the roofs in the desiccation plots.

The roofs reduced throughfall to the ground by 52\% in March and 41\% in April 2007, and by 7384\% between May 2007 and May 2008 (Fig. 1). Trenches $(40 \mathrm{~cm}$ deep $\times 20 \mathrm{~cm}$ wide $)$ were dug around all plots and lined with plastic sheet to sever tree roots in the topsoil, where the density of fine and coarse roots was highest, and divert surface flow from upslope areas during heavy rainfall.

Microclimatological and soil physical

and chemical measurements

An automatic weather station installed $2 \mathrm{~m}$ above the canopy of a cocoa stand $15 \mathrm{~m}$ from plot 1 was used to record air temperature and relative humidity (CS 215, Campbell Scientific Inc., Logan, UT, USA), incident global radiation (CS 300, Campbell Scientific Inc.) and rainfall (ARG 100, Campbell Scientific Inc.) at $5 \mathrm{~s}$ intervals; data were stored as 30-min averages using a CR800 datalogger (Campbell Scientific Inc.).

Three soil pits were excavated to a depth of $3 \mathrm{~m}$ in all plots to conduct soil physical and chemical inventories and provide access to deeper soil horizons for ongoing measurements. The pits were covered between measurements using plastic sheets and wooden plates to prevent evaporation from the pit walls. Laboratory desorption curves indicated that a matric potential of $-1.5 \mathrm{MPa}$ ('permanent wilting point') corresponded to a volumetric soil water content of $22-25 \%$ at depths of 5 and $40 \mathrm{~cm}$, and to $28 \%$ at $75 \mathrm{~cm}$ (van Straaten and Veldkamp, pers. comm.). Volumetric soil water content was monitored by time domain reflectometry probes (TDR, C61 6 probes, Campbell Scientific Inc.) installed horizontally in the pit walls at depths of $10 \mathrm{~cm}(n=3$ per plot $), 75 \mathrm{~cm}$ $(n=3)$ and $150 \mathrm{~cm}(n=1)$; these were logged at $1 \mathrm{~h}$ intervals (CR1000 datalogger Campbell Scientific Inc.). The high stone content limited the number of probes installed at $75 \mathrm{~cm}$ depth in plots 1,4 and 5 $(n=2)$. The probes were calibrated for the local soil as described by Veldkamp and O'Brien (2000).
Analysis of stand structure and aboveand belowground biomass

The cocoa trees in all six plots were individually labeled, and their stem diameter $80 \mathrm{~cm}$ above the ground and tree height were measured using dendrometer tapes (resolution $0.1 \mathrm{~mm}$ ) and a Vertex height meter (Haglöf, Langsele, Sweden). Aboveground biomass (wood of stems, branches and twigs) was estimated from stem diameter using an allometric relationship established in the nearby Palolo and Napu valleys (40 km north-east of Marena; Smiley and Kroschel 2008). This approach also provided biomass estimates for large, coarse and fine roots. Aboveground biomass of the overstorey Gliricidia trees was estimated using the allometric regression described by Foroughbakhch et al. (2006) based on measurements of stem diameter in all stands. Smiley and Kroschel (2008) obtained a root/shoot ratio for Gliricidia of 2.05 in the nearby Palolo/Napu stands, and this was applied to the Marena stand on the assumption that the growth habit was similar in both stands. To estimate the leaf area index (LAI) of the cocoa and Gliricidia trees separately, hemispherical photographs were taken using a fisheye lens at heights of $0.8 \mathrm{~m}$ below and $5 \mathrm{~m}$ above the cocoa canopy, but under the Gliricidia canopy. These measurements were made in August 2006 at 12 locations per plot in a rectangular grid $(10 \mathrm{~m} \times$ $12.5 \mathrm{~m}$ ) at the locations of the litter traps (see below). The photographs were analyzed using WinScanopy software. The effective $\mathrm{LAI}_{\text {(LAIeff) }}$ was calculated after Bonhomme and Chartier (1972) for a zenith angle of $57.5^{\circ}$ and the true $\mathrm{LAI}_{(\mathrm{LAItrue})}$ was derived by dividing $\mathrm{LAI}_{\text {eff }}$ by the clumping index (CI) calculated for each image as described by Lang and Xiang (1986). To obtain the leaf biomass of the cocoa and Gliricidia trees in August 2006, the LAI values were divided by the corresponding mean specific leaf area (SLA) determined using the litter trap samples.

To determine the depth distribution of fine root (diameter $<2 \mathrm{~mm}$ ), coarse root $(20-50 \mathrm{~mm})$ and large root biomass $(>50 \mathrm{~mm})$, two soil pits per plot were dug before (December 2006) and after the drought period (May-June 2008) to a depth of $3 \mathrm{~m}$. In each pit, $50 \mathrm{~cm} \times 50 \mathrm{~cm}$ wide soil monoliths were excavated and sliced into $20 \mathrm{~cm}$-thick segments, enclosed in polyethylene bags and transported to the University of Palu for analysis. All roots within each 
monolith were washed out using a $0.25 \mathrm{~mm}$ sieve, separated into living and dead fine and coarse root fractions and sorted by species (cocoa, Gliricidia and coconut). Criteria for separating live and dead root mass were the degree of root elasticity and/or an inspection of the root cross-sections to reveal the disintegration of root stele, pericycle and periderm which occurs in dead roots. The roots of cocoa, Gliricidia and coconut were distinguished by their colour, branching pattern, diameter and the presence or absence of root nodules. Fine and coarse roots of cocoa have a dark brown periderm and even small diameter roots are already strongly lignified. The fine and coarse roots of Gliricidia are light brown to ochre in colour, and the former are very soft and many have nodules. Coconut roots were always thicker than $7 \mathrm{~mm}$, even at their root tips, and were classified as fine roots when their diameter was $<20 \mathrm{~mm}$ as significant lignification was observed only in roots $>20 \mathrm{~mm}$ in diameter. The root mass of the herbaceous layer was negligible and the data were omitted. When the desiccation period ended in June 2008, the root systems of six cocoa and three Gliricidia trees in the centre of each of the roof and control plots were completely excavated to determine the three-dimensional extension of fine and coarse roots. Most of these trees were located $>8 \mathrm{~m}$ from the plot boundaries. Twenty $\mathrm{cm}$ thick soil layers were excavated within a radius of $100 \mathrm{~cm}$ around the stem until the tip of the tap root was reached at a maximum depth of $160 \mathrm{~cm}$. Root biomass distribution data were compiled for three distance classes from the tree stem $(0-50,50-100$ and $>100 \mathrm{~cm})$. Mean root biomass in each plot was calculated from the excavations, tree densities within the stand, and the soil pit data. Total root biomass (fine, coarse and large) of Gliricidia was estimated based on the root/shoot ratios determined by Smiley and Kroschel (2008) in the nearby Palolo/ Napu stands and our stem diameter measurements.

Measurement of seasonal biomass dynamics and productivity

To measure increments in stem diameter, 10 cocoa and four Gliricidia trees were randomly selected in each stand and fitted with dendrometer tapes (UMS, Munich, Germany) at a height of $50 \mathrm{~cm}$ above the ground; these were read at fortnightly intervals between March 2007 and March 2008. The increments in stem basal area were used to estimate aboveground production of stem, branch and twig wood based on the allometric equations relating stem diameter to wood biomass given by Smiley and Kroschel (2008) for cocoa and by Foroughbakhch et al. (2006) for Gliricidia. The increments in basal stem area also allowed approximate estimates to be obtained for the production of large diameter roots for both tree species based on the root/shoot ratios determined by these authors.

Litter fall of leaves and reproductive organs was monitored between March 2007 and March 2008 using 12-1 buckets (aperture $75 \mathrm{~cm} \times 75 \mathrm{~cm}$ ) per plot, arranged at a spacing of $10 \mathrm{~m} \times 12.5 \mathrm{~m}$ in a rectangular grid. The litter was sorted by species and analyzed to determine leaf biomass. The 10 cocoa trees per plot monitored for stem growth were also examined fortnightly for the abundance of buds, flowers and fruits to establish the phenology of reproductive growth. On each of the 27 observation dates, the numbers of buds, flowers, and cocoa pods were counted for all trees. The yield of cocoa pods and beans was recorded separately for all trees in the core zone of the plots, including pod and bean fresh weight, the sun-dry weight of beans and the oven-dry weight $\left(70^{\circ} \mathrm{C}, 3\right.$ days) of pod and bean subsamples.

Water status and hydraulic properties of roots

Root water potential was measured for cocoa and Gliricidia in both the roof and control plots in February 2007, before the onset of the desiccation treatment, and on four occasions during the drought period. On all occasions, 18 root branches (diameter 3-5 mm with all appending fine roots) of cocoa and nine roots of Gliricidia per treatment were carefully excavated from the topsoil at randomly selected locations, cut and immediately used to determine their xylem water potential using a Scholander pressure chamber (M600, Mosler Tech Support, Berlin, Germany).

To estimate the proportion of embolized vessels in the xylem of coarse roots, the axial hydraulic conductivity of root segments (diameter 3-5 mm) of cocoa in the roof and control plots was measured in December 2006, and February, July and September 2007. Six cocoa trees per plot were randomly selected and three superficial branch root segments per tree were excised and analysed for actual and maximum 
hydraulic conductivity as described by Sperry et al. (1988). Coarse root segments $\geq 12 \mathrm{~cm}$ in length were immediately transferred to polyethylene bags filled with cold water and transported to the laboratory in Palu, where they were stored at $4^{\circ} \mathrm{C}$ prior to measurement. To measure their axial hydraulic conductivity, gravity-induced flow with a potential difference of ca. $6-7 \mathrm{kPa}$ per $5 \mathrm{~cm}$ length was applied. In the first round of hydraulic conductivity measurements, a flow period of 5 min was allowed to determine actual conductivity. Water passing through the segment was collected at its distal end in preweighed plastic cups for subsequent quantification. The root segments were then flushed for $5 \mathrm{~min}$ at a potential difference of $0.12 \mathrm{MPa}$ to remove air bubbles from the vessels before making a second measurement to determine the maximum axial conductivity of the unblocked xylem. Flushing and subsequent flow measurements were repeated at least twice to approach maximum conductivity values. The percentage reduction in hydraulic conductivity was taken as a measure of the proportion of embolized vessels in the root xylem.

\section{Statistical analyses}

To test for significant differences between the roof and control treatments in the biomass and production fractions (leaves, stem and branch wood, roots, cocoa beans, pods without beans), root water potential and the percentage reduction in hydraulic conductivity of the root xylem, non-parametric analyses of variance (Kruskal-Wallis test) and subsequent Mann-Whitney two-sample tests (Wilcoxon $U$-test) were conducted using SAS software (version 9.1; SAS Institute, Cary, NC, USA).

\section{Results}

\section{Soil moisture}

Volumetric water content $(\theta)$ was consistently high in the control plots $\left(0.38-0.48 \mathrm{~m}^{3} \mathrm{~m}^{-3}\right.$ at depths of 10 and $75 \mathrm{~cm}$, and $0.30-0.37 \mathrm{~m}^{3} \mathrm{~m}^{-3}$ at $150 \mathrm{~cm}$; Fig. 3). Rainless periods exceeding 2 weeks occurred only in January 2008. The roof plots showed a progressive decrease in $\theta$ from March 2007 to reach a minimum in January and February 2008, when $\theta$ was

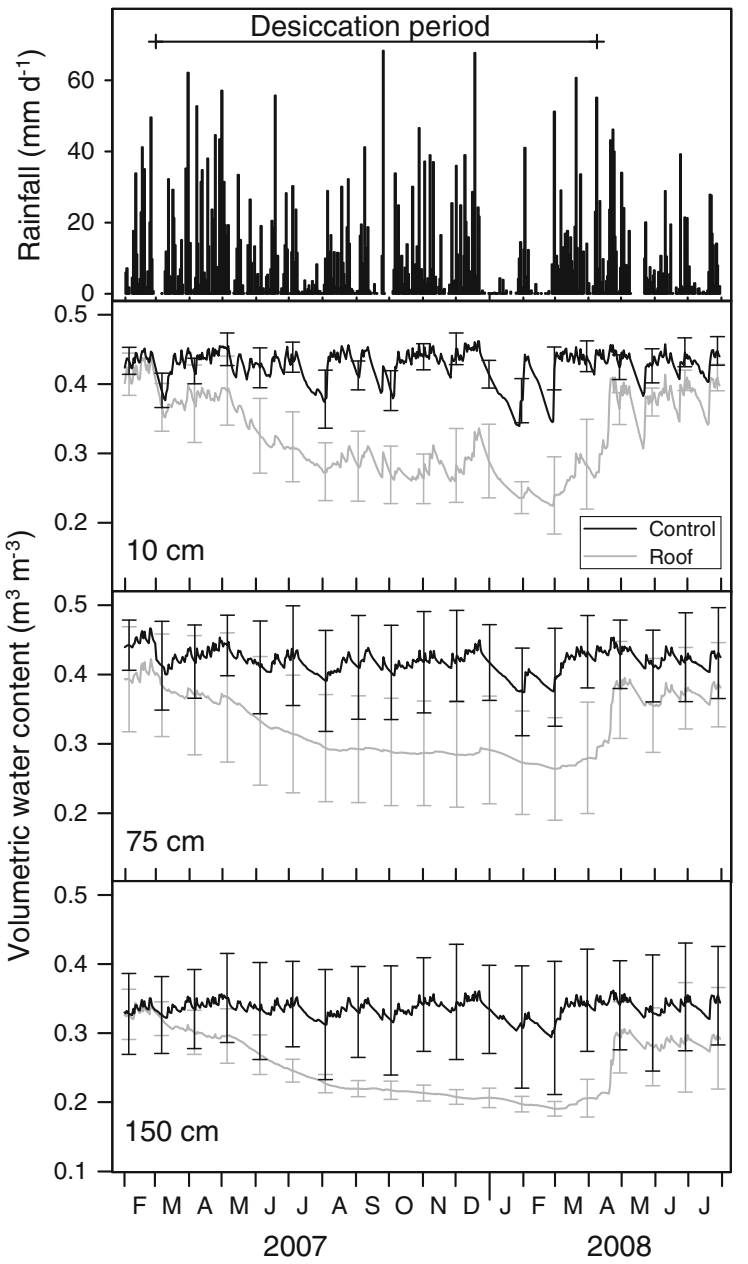

Fig. 3 Daily rainfall and volumetric water content $(\theta)$ at soil depths of 10,75 and $150 \mathrm{~cm}$ in the roof and control treatments in the cocoa agroforest in Marena. $\theta$ was measured hourly at soil depths of 10 and $75 \mathrm{~cm}(n=9)$ and $150 \mathrm{~cm}(n=3)$. Daily mean values \pm SD are shown for $\theta$

$0.12-0.15 \mathrm{~m}^{3} \mathrm{~m}^{-3}$ lower than in the control plots. The timecourses of $\theta$ were similar for all sampling depths, although the deepest horizon, with its higher bulk density, invariably exhibited lower values. The minimum values recorded during winter 2007/ 2008 were close to the permanent wilting point (-1.5 MPa; van Straaten and Veldkamp, pers. comm.).

Aboveground/belowground biomass partitioning

Stand structure was very uniform in all plots and showed no significant variation between treatments (Table 1). The 6-year-old cocoa stands and their shade trees had an estimated total above- plus 


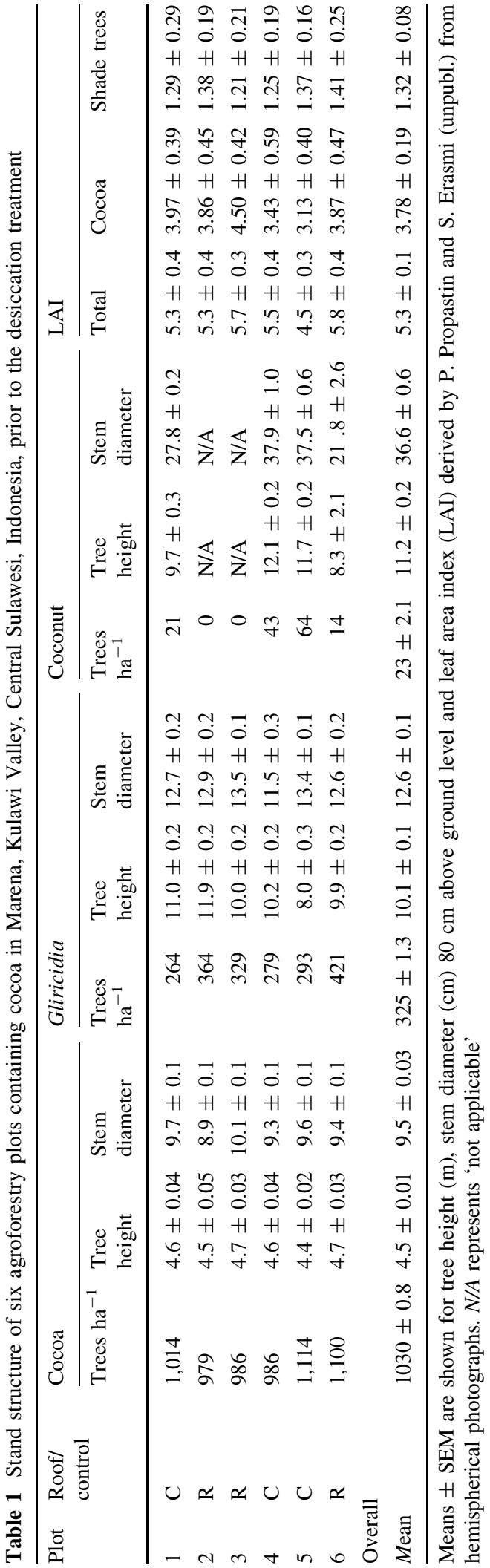

belowground biomass of $40-42 \mathrm{Mg} \mathrm{ha}^{-1}$ prior to the imposed drought period, with ca. $20 \%$ of this being contributed by Gliricidia and the remainder by cocoa (Table 2); the biomass of the small number of coconut trees was not determined. The roof and control treatments did not differ significantly for either total stand biomass or for leaf, wood or root biomass. Estimated leaf biomass was 4.8 and $5.4 \mathrm{Mg} \mathrm{ha}^{-1}$ in the control and roof treatments, while the cocoa trees contributed remarkably high stem and branch wood biomasses of ca. $22 \mathrm{Mg} \mathrm{ha}^{-1}$. The estimated total root biomass (large, coarse and fine roots) of cocoa ranged between 5.7 and 7.2 $\mathrm{Mg} \mathrm{ha}^{-1}$, corresponding to root/shoot ratios of $0.22-0.28$ in the control and roof plots. For the more irregularly spaced Gliricidia trees, estimated root biomasses of 2.5 and $3.1 \mathrm{Mg} \mathrm{ha}^{-1}$ were obtained for the control and roof plots using the allometric equations given by Smiley and Kroschel (2008; root:shoot ratio $=0.49$ ).

Effects of drought on root distribution and root water status

The excavations immediately before the drought treatment revealed a superficial distribution of roots in the soil profile, with $>83 \%$ of fine roots and $>86 \%$ of the coarse roots of cocoa being located in the upper $40 \mathrm{~cm}$ (Fig. 4). However, significant quantities of fine root biomass in cocoa were present to a depth of $100 \mathrm{~cm}$, while the deepest fine roots reached $200 \mathrm{~cm}$; coarse roots extended to $150 \mathrm{~cm}$. In the uppermost $20 \mathrm{~cm}$, root density for cocoa was $270-280 \mathrm{~g} \mathrm{~m}^{-3}$ for fine roots and $55-71 \mathrm{~g} \mathrm{~m}^{-3}$ for coarse roots. No significant differences in root biomass were detected between the roof and control treatments either at the beginning or end of the drought treatment (Fig. 4). Comparison of the fine root biomass of cocoa at distances of 0-50, 50-100 and $>100 \mathrm{~cm}$ from the stem revealed no clear differences in total biomass or vertical root distribution (Fig. 5), although coarse and large roots $(2-150 \mathrm{~mm}$ in diameter) were concentrated within $50 \mathrm{~cm}$ of the cocoa stems and few extended to distances $>100 \mathrm{~cm}$.

The roots of Gliricidia, in particular the fine roots, penetrated much deeper than those of cocoa, being present in considerable numbers to a depth of $250 \mathrm{~cm}$ (Fig. 6). The fine roots of Gliricidia were more 
Table 2 Comparison of biomass fractions ( $\mathrm{Mg} \mathrm{ha}^{-1} \pm \mathrm{SEM}, n=3$ ) for cocoa and Gliricidia trees in the control and roof plots prior to the drought treatment

\begin{tabular}{|c|c|c|c|c|c|c|}
\hline \multirow[t]{2}{*}{ Biomass fraction } & \multicolumn{3}{|l|}{ Control } & \multicolumn{3}{|l|}{ Roof } \\
\hline & Cocoa & Gliricidia & Total & Cocoa & Gliricidia & Total \\
\hline Leaves & $3.76 \pm 0.26^{\mathrm{a}}$ & $1.00 \pm 0.05^{\mathrm{A}}$ & $4.76 \pm 0.43^{\alpha}$ & $4.37 \pm 0.32^{\mathrm{a}}$ & $1.03 \pm 0.07^{\mathrm{A}}$ & $5.40 \pm 0.53^{\alpha}$ \\
\hline Stem + branches & $22.32 \pm 0.99^{\mathrm{a}}$ & $4.17 \pm 0.78^{\mathrm{A}}$ & $26.49 \pm 2.09^{\alpha}$ & $21.35 \pm 1.48^{\mathrm{a}}$ & $5.36 \pm 1.06^{\mathrm{A}}$ & $26.72 \pm 2.63^{\alpha}$ \\
\hline Roots & $5.74 \pm 1.42^{\mathrm{a}}$ & $2.52 \pm 0.39^{\mathrm{A}}$ & $8.26 \pm 1.69^{\alpha}$ & $7.21 \pm 1.76^{\mathrm{a}}$ & $3.12 \pm 0.54^{\mathrm{A}}$ & $10.33 \pm 2.08^{\alpha}$ \\
\hline Total & $31.80 \pm 2.15^{\mathrm{a}}$ & $7.69 \pm 1.18^{\mathrm{A}}$ & $39.51 \pm 3.26^{\alpha}$ & $32.89 \pm 2.32^{\mathrm{a}}$ & $9.51 \pm 1.64^{\mathrm{A}}$ & $42.45 \pm 3.68^{\alpha}$ \\
\hline
\end{tabular}

Since fine and coarse root biomass remained constant over time and no significant drought treatment effect was detected, the table presents the detailed root biomass data for cocoa determined after the drought period at different distance classes from the stem base $(0-50 \mathrm{~cm}, 50-100 \mathrm{~cm},<100 \mathrm{~cm} ; n=6)$. Different letters indicate significant differences between roof and control plots $(P<0.05$; lower case letters: cocoa, upper case letters: Gliricidia, Greek letters: total biomass)

evenly distributed in the soil profile than those of cocoa and did not exhibit such a pronounced density peak in the $0-20 \mathrm{~cm}$ horizon. The biomass of coarse and large roots of Gliricidia reached a maximum of $40 \mathrm{~g} \mathrm{~m}^{-3}$ at $30 \mathrm{~cm}$ depth, greatly exceeding the corresponding value for cocoa $\left(<5 \mathrm{~g} \mathrm{~m}^{-3}\right)$. In contrast to cocoa, the fine root biomass of Gliricidia was smaller at the end than at the beginning of the drought period at most soil depths in both the roof and the control plots (Fig. 6b). Complete excavation of the root systems of six Gliricidia trees revealed no significant difference between the desiccation and control treatments (data not shown), with the deepest roots extending to $250 \mathrm{~cm}$ in both treatments.

The decrease in water potential $\left(\Psi_{\mathrm{r}}\right)$ in the coarse roots of cocoa (diameter 3-5 mm) was much more pronounced in the roof treatment than in the control during the desiccation period (Fig. 7a). Thus, $\Psi_{\mathrm{r}}$ in the roof treatment decreased from ca. $-0.12 \mathrm{MPa}$ in February 2007 to $-0.95 \mathrm{MPa}$ in September 2007 after 6 months of throughfall displacement before increasing again. The roots of the control trees maintained median $\Psi_{\mathrm{r}}$ values of -0.15 to $-0.20 \mathrm{MPa}$ for most of the desiccation period, and reached a minimum of $-0.40 \mathrm{MPa}$ in September 2007. $\Psi_{\mathrm{r}}$ values for droughted cocoa trees were $0.3-0.5 \mathrm{MPa}$ lower than in control trees. Gliricidia roots reached a seasonal minimum of $\Psi_{\mathrm{r}}$ between September 2007 and March 2008, although the values did not differ between the roof and control treatments (Fig. 7b). The lowest median $\Psi_{\mathrm{r}}$ values for Gliricidia $(-0.5 \mathrm{MPa})$ were much higher than in cocoa. The coarse roots of cocoa showed no significant difference between the roof and control treatments with respect to the extent of the reduction in axial hydraulic conductivity caused by xylem embolism (Fig. 7c), although the apparent degree of embolism increased in both treatments between February and September 2007 with ongoing desiccation.

Effects of drought on aboveground biomass production and cocoa bean yield

Cocoa and Gliricidia both showed remarkably high above- and belowground net primary productivity (NPP) between March 2007 and February 2008, and there was no significant difference between the control (13.7 Mg ha ${ }^{-1}$ year $^{-1}$ ) and roof treatments (14.4 $\mathrm{Mg} \mathrm{ha}^{-1}$ year $^{-1}$; Table 3). A remarkably large proportion of NPP (total of leaf, wood and root production) was contributed by leaf turnover (ca. $45 \%$ ), while stem and branch wood production (3.0$3.3 \mathrm{Mg} \mathrm{ha}^{-1}$ year $^{-1}$ ) comprised only $22-23 \%$ of NPP. Cocoa bean and pod production comprised $31-37 \%$ of NPP (bean production alone was $7-9 \%$; Table 3). Relative to their contribution to the total number of trees present (ca. 30\%), individual Gliricidia trees were more productive than cocoa, providing $37-41 \%$ of system NPP. Leaf production was particularly high in Gliricidia.

Contrary to expectation, the 13-month desiccation period had no significant effect on the primary production of either cocoa or Gliricidia; thus, leaf biomass production was unaffected in both species, although the wood increment was slightly, but significantly, higher for cocoa in the roof plots than in the control plots. Cocoa bean yield was $10 \%$ lower in the roof treatment during the 13-month 

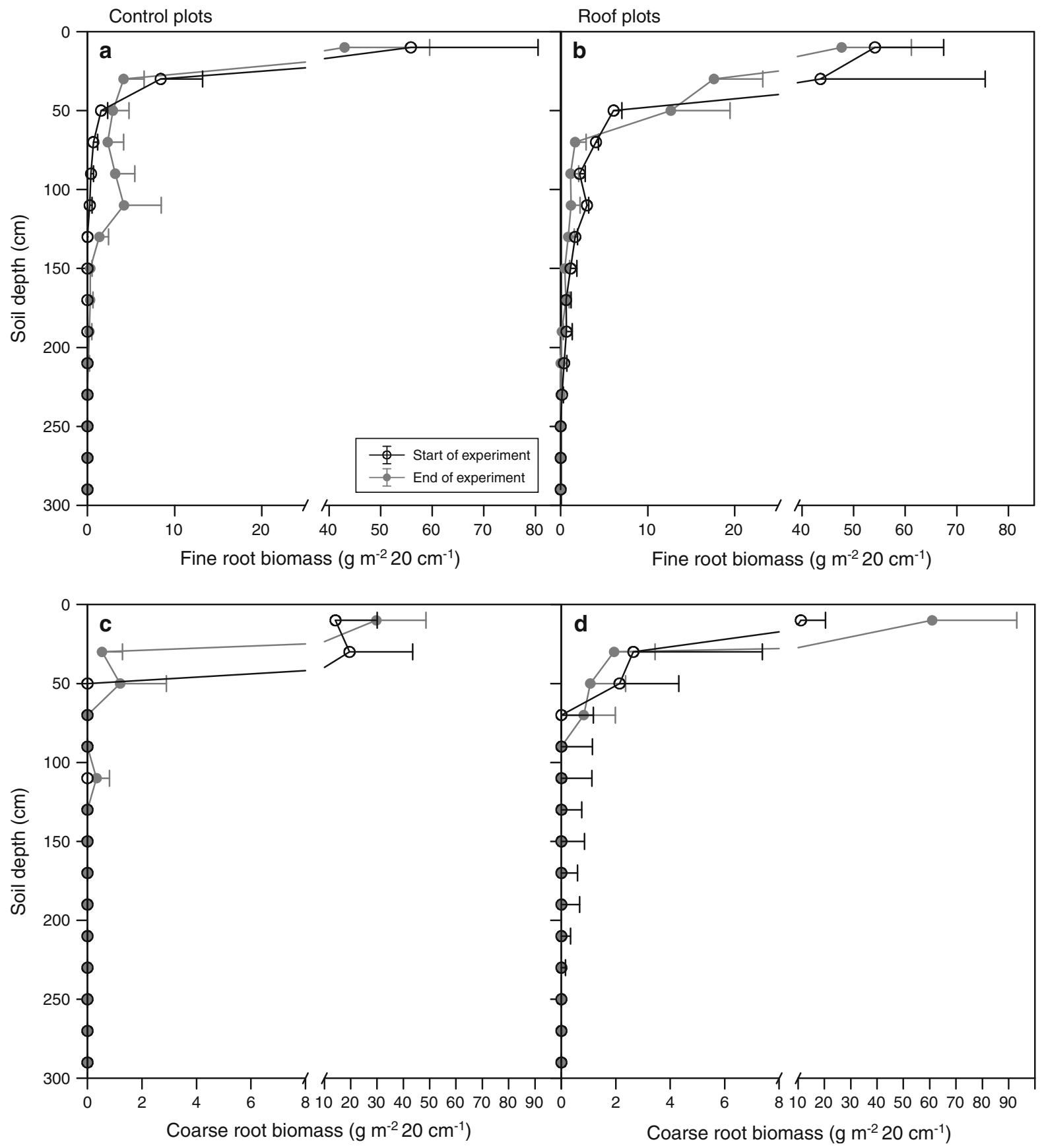

Fig. 4 Vertical distribution of fine $(\mathbf{a}+\mathbf{b})$ and coarse roots $(\mathbf{c}+\mathbf{d})$ of cocoa at a minimum distance to the nearest tree of $1 \mathrm{~m}$ in the control and the roof plots at the start and the end of

treatment, although this difference was not significant, but exhibited a significant reduction of ca. $53 \%$ in the roof treatment relative to control trees the 13-month desiccation period. Mean values \pm SEM are shown $(n=3)$. Coarse roots refer to diameters of $2-150 \mathrm{~mm}$

during the first fructification event shortly after the desiccation treatment ended (April-July 2008; Fig. 8). 

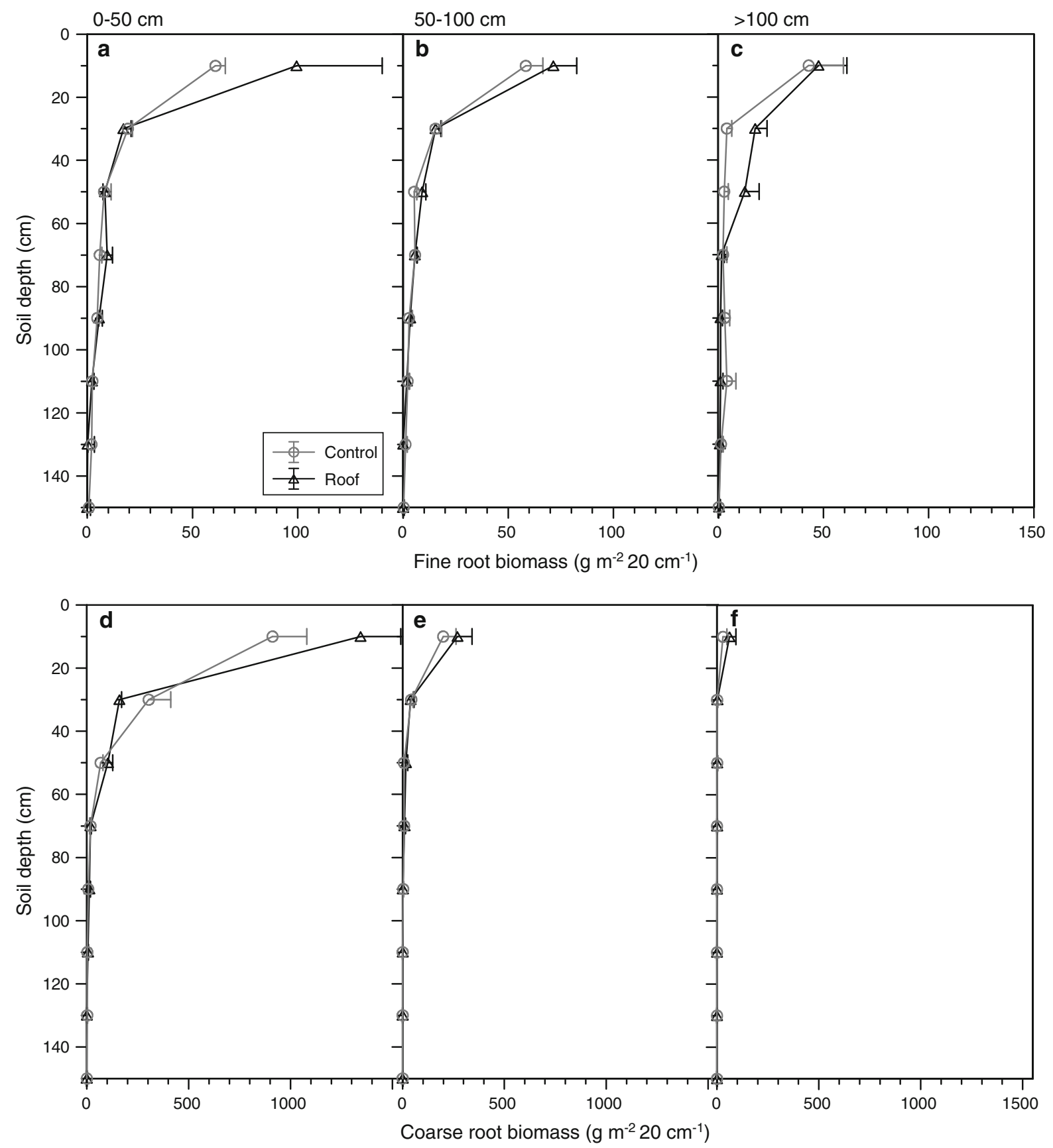

Fig. 5 Vertical distribution of fine (a-c) and coarse roots (2-150 mm diameter, $(\mathbf{d}-\mathbf{f})$ of cocoa in the roof and control plots at distances of 0-50, 50-100 and $>100 \mathrm{~cm}$ from the stem base at the end of the experiment (June 2008). Mean values \pm SEM are shown $(n=6)$

\section{Discussion}

Drought responses at leaf and stem levels

During the 13-month desiccation period, almost $80 \%$ of the throughfall which would normally have occurred in the roof plots was intercepted and channeled outside the experimental plots, inducing a persistent depletion of soil moisture content and causing soil matric potential $\left(\Psi_{\mathrm{s}}\right)$ to approach permanent wilting point throughout much of the rooting profile. The duration of the drought period 

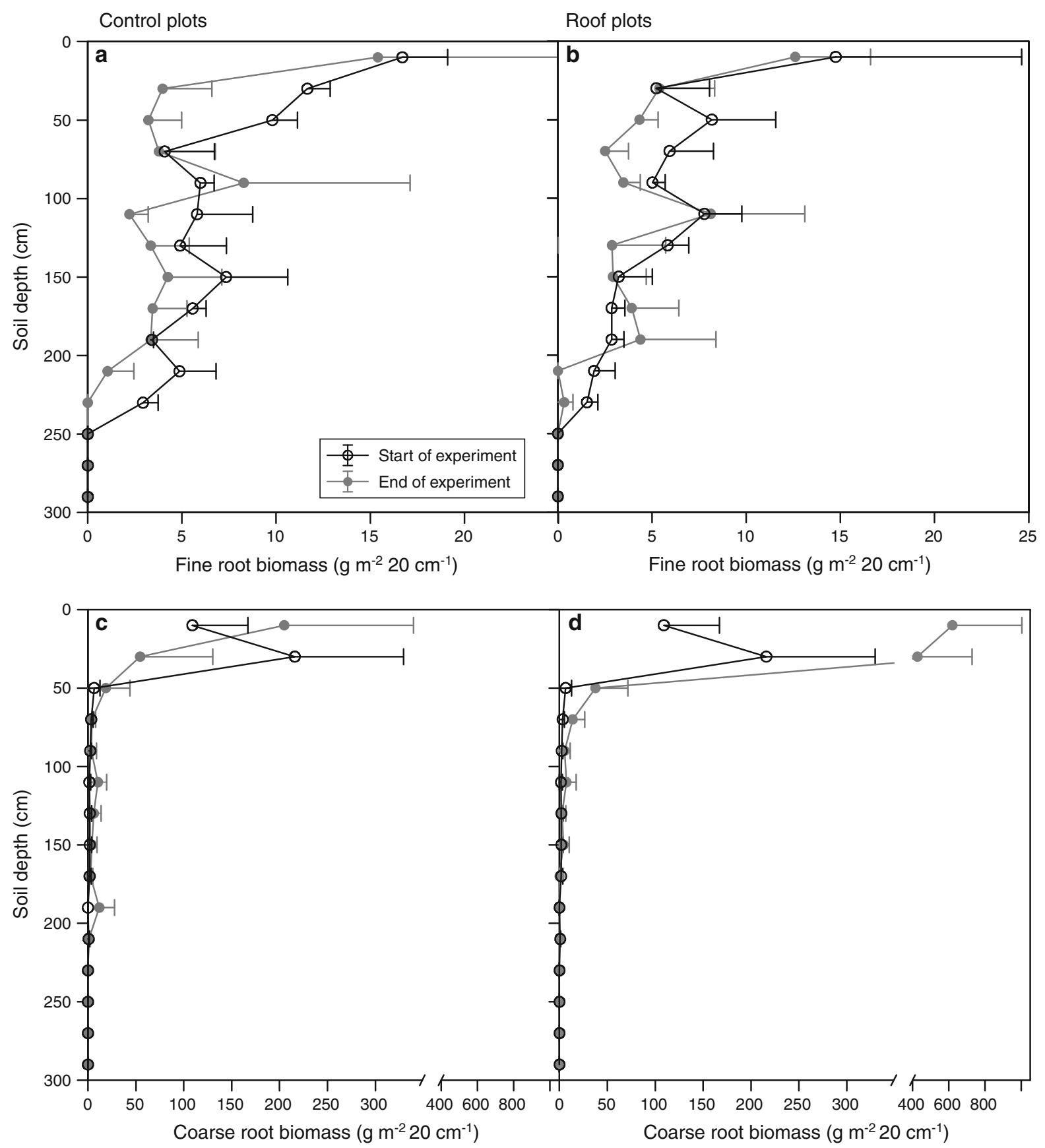

Fig. 6 Vertical distribution of fine $(\mathbf{a}+\mathbf{b})$ and coarse roots $(\mathbf{c}+\mathbf{d})$ of Gliricidia sepium at a minimum distance to the nearest tree of $1 \mathrm{~m}$ before (December 2006) and after (June 2008) the desiccation period in the control and roof plots. Mean values \pm SEM

approached or exceeded severe ENSO-drought events such as occurred in Kalimantan in 1997/1998 (Wooster and Strub 2002; Boyd et al. 2006). With respect to the physiological meaning of low soil matric potentials, the precise value of the 'permanent wilting point' for cocoa remains unclear. However, independently of our drought intensity assessment based on $\Psi_{\mathrm{s}}$, Schwendenmann et al. (2010) reached similar conclusions when calculating the fluctuation of 'relative extractable water' in the soil profile of the 
Fig. 7 a and b Volumetric soil water content, and the water potential of coarse roots of cocoa and Gliricidia trees, and c the reduction in conductivity of cocoa roots prior to (February 2007) and during the early (July-September 2007) and late stages (March 2008) of the 13month drought treatment. Box-whisker-plots with median, 25 and $75 \%$ percentiles and minima and maxima are shown. Asterisks denote significant differences in root water potential $(P<0.05)$ between the roof and control treatments
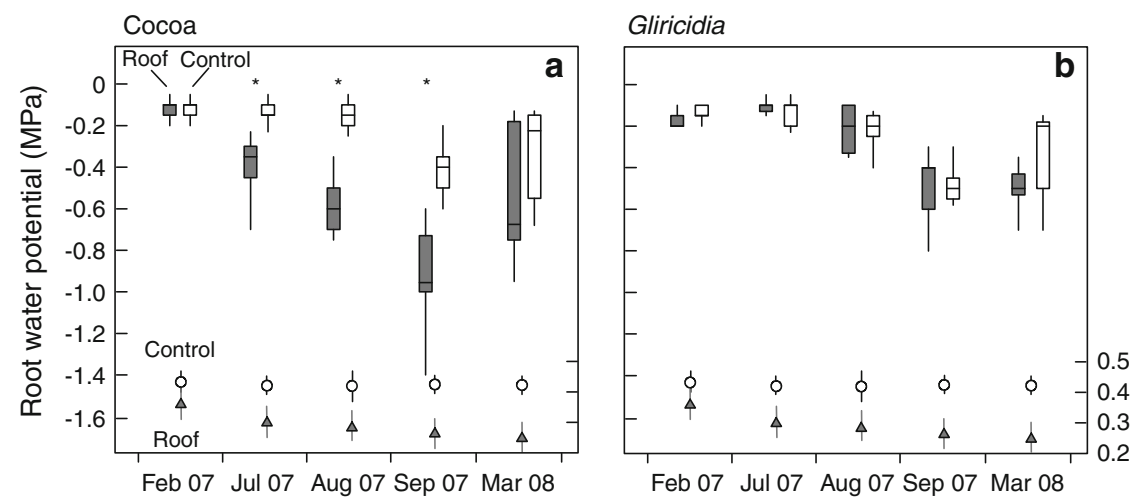

Feb 07 Jul 07 Aug 07 Sep 07 Mar 08

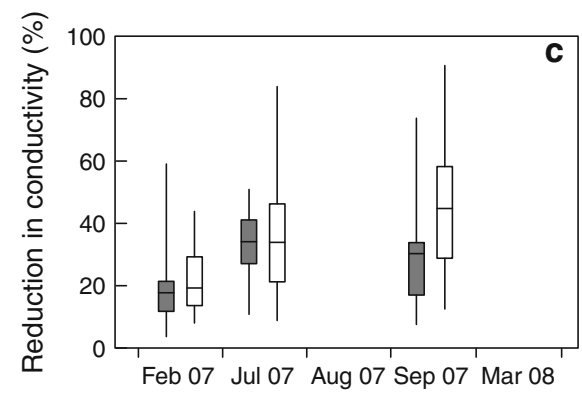

Table 3 Components of net primary production by cocoa and Gliricidia trees between March 2007 and February 2008 in the roof and control plots $\left(\mathrm{Mg} \mathrm{ha}^{-1}\right.$ year $\left.^{-1} \pm \mathrm{SEM}, n=3\right)$

\begin{tabular}{|c|c|c|c|c|c|c|}
\hline \multirow[t]{2}{*}{ Biomass production } & \multicolumn{3}{|l|}{ Control } & \multicolumn{3}{|l|}{ Roof } \\
\hline & Cocoa & Gliricidia & Total & Cocoa & Gliricidia & Total \\
\hline Leaves & $2.77 \pm 0.09^{\mathrm{a}}$ & $3.91 \pm 0.32^{\mathrm{A}}$ & $6.26 \pm 0.23^{\alpha}$ & $2.98 \pm 0.24^{\mathrm{a}}$ & $3.87 \pm 0.41^{\mathrm{A}}$ & $6.85 \pm 0.24^{\alpha}$ \\
\hline Cocoa beans & $0.74 \pm 0.18^{\mathrm{a}}$ & N/A & $0.74 \pm 0.18^{\alpha}$ & $0.67 \pm 0.03^{\mathrm{a}}$ & N/A & $0.67 \pm 0.03^{\alpha}$ \\
\hline Pods without beans & $2.43 \pm 0.90^{\mathrm{a}}$ & N/A & $2.43 \pm 0.90^{\alpha}$ & $2.20 \pm 0.09^{\mathrm{a}}$ & N/A & $2.20 \pm 0.09^{\alpha}$ \\
\hline Stem + branches & $1.81 \pm 0.21^{\mathrm{a}}$ & $1.20 \pm 0.22^{\mathrm{A}}$ & $3.01 \pm 0.32^{\alpha}$ & $2.35 \pm 0.21^{\mathrm{b}}$ & $0.97 \pm 0.31^{\mathrm{A}}$ & $3.32 \pm 0.47^{\alpha}$ \\
\hline Roots & $0.71 \pm 0.08^{\mathrm{a}}$ & $0.59 \pm 0.11^{\mathrm{A}}$ & $1.30 \pm 0.14^{\alpha}$ & $0.93 \pm 0.08^{\mathrm{b}}$ & $0.47 \pm 0.15^{\mathrm{A}}$ & $1.40 \pm 0.21^{\alpha}$ \\
\hline Total & $8.46 \pm 0.14^{\mathrm{a}}$ & $5.70 \pm 0.32^{\mathrm{A}}$ & $13.74 \pm 0.41^{\alpha}$ & $9.13 \pm 0.57^{\mathrm{a}}$ & $5.31 \pm 0.66^{\mathrm{A}}$ & $14.44 \pm 0.53^{\alpha}$ \\
\hline
\end{tabular}

Different letters indicate significant differences between roof and control plots $(P<0.05$; lower case letters, cocoa; upper case letters, Gliricidia; Greek letters: total biomass). N/A represents 'not applicable'

stand examined here using data for maximum observed water storage and actual soil moisture content. They identified a 9-month drought period during which pronounced water deficits were experienced, substantiating our assessment based on soil matric potential. Some fluctuation in subsoil water content was observed after closing the roofs in the present study which may have resulted from penetration of the remaining throughfall water to the subsoil, although fluctuation in soil moisture resulting from local infiltration would have been expected to be greatest in the surface soil horizon; however, this would not have been monitored by the shallowest TDR probes installed at a depth of $10 \mathrm{~cm}$. Stemflow is a less likely cause of fluctuations in soil moisture as this has been shown to comprise $<2 \%$ of rainfall in cocoa plantations (de Miranda 1994; Dietz et al. 2006).

Neither cocoa nor Gliricidia showed significant increases in pre-senescent leaf shedding in response to drought, as leaf production was high in the roof treatment $\left(6.85 \mathrm{Mg} \mathrm{ha}^{-1} \mathrm{year}^{-1}\right.$ ) and both species maintained their leaf area throughout the desiccation period. The LAI of cocoa was ca. 3.8 in both 


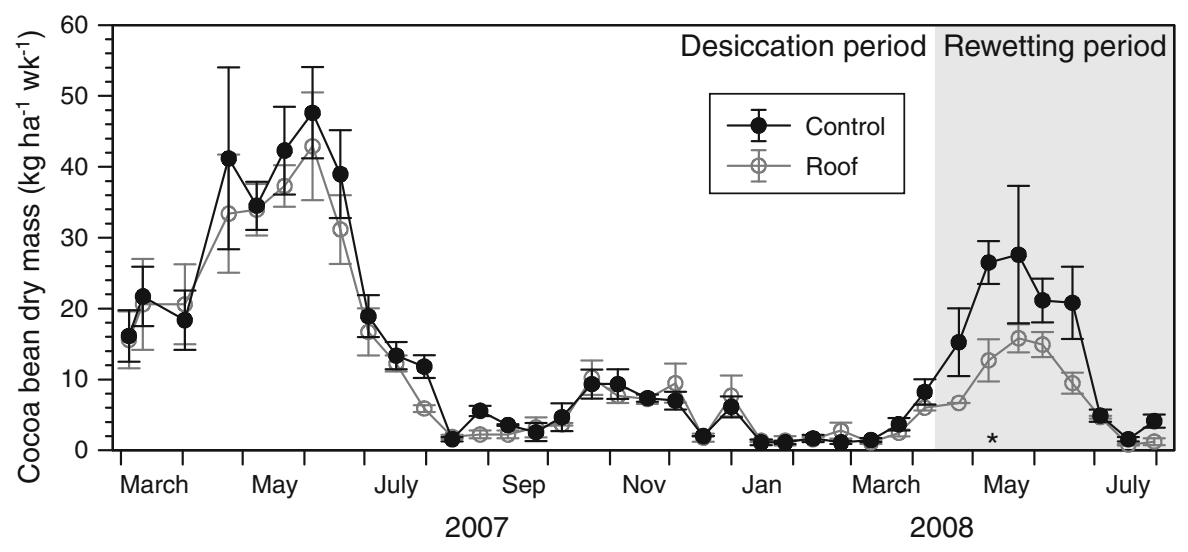

Fig. 8 Seasonal variation in the dry biomass of cocoa beans harvested at biweekly intervals between March 2007 and July 2008 (means \pm SEM; $n=3$ ); the drought period extended

treatments, close to that reported for a shaded cocoa plantation in humid Bahia, Brazil (3.9; Miyaji et al. 1997). In many tropical and temperate tree species, pre-senescent leaf shedding and permanent reductions in leaf area represent early responses to drought, as observed during ENSO-droughts in South-east Asian lowland forests (Kogan 2000; Nagai et al. 2007), or in a throughfall reduction experiment in a tropical lowland forest in Amazonia (Nepstad et al. 2002). According to Zuidema et al. (2005), the rates of leaf production and abscission in Theobroma depend largely on the water and light regimes. The present observations contrast with previous studies in which reductions in leaf area in cocoa during severe drought (Orchard and Saltos 1988) were accompanied by decreased $\mathrm{CO}_{2}$ assimilation (Hutcheon 1977), flowering and yield (Sale 1970; Khan et al. 1988).

The absence of reductions in stem and branch wood production in cocoa and Gliricidia in the present study is surprising. Unlike temperate trees, which often show reductions in stem increments with a lag phase of up to 1 year following drought, woody species in tropical perhumid climates frequently exhibit woody growth responses within two or 3 months after the beginning of a dry period (Schöngart et al. 2005). However, there is little information concerning seasonal woody growth dynamics in cocoa, whose seedlings exhibit alternating phases of shoot and root growth (Taylor and Hadley 1987), suggesting that phases of enhanced wood and/or leaf growth coincide with periods of reduced root growth. Further research involving from March 1, 2007 to April 10, 2008. The asterisk in May 2008 denotes a significant difference between the roof and control treatments $(P<0.05)$

synchronous monitoring of root and stem growth during periods of drought are needed to elucidate this possibility.

\section{Drought response of roots}

The estimated total fine root biomass (diameter $<2 \mathrm{~mm}$ ) for cocoa $\left(62-84 \mathrm{~g} \mathrm{~m}^{-2}\right)$ for the Marena plantation is comparable to the values of 40 $80 \mathrm{~g} \mathrm{~m}^{-2}$ reported by Kummerow et al. (1981, 1982), but is lower than those obtained by Muñoz and Beer (2001) and Harteveld et al. (2007) for shaded cocoa plantations (100-185 and ca. $220 \mathrm{~g} \mathrm{~m}^{-2}$, respectively). Harteveld et al. (2007) concluded that cocoa agroforestry systems in Sulawesi maintain a much smaller fine root biomass than the native tropical moist forests they have replaced (ca. $400 \mathrm{~g} \mathrm{~m}^{-2}$ ). Possession of a small fine root biomass might increase the drought susceptibility of Theobroma by reducing its ability to absorb water but, perhaps more importantly, the fine roots of cocoa were located primarily in the upper soil horizons where they are rapidly exposed to drought. Indeed, Silva and Kummerow (1998) reported a mean functional life of only 3 days for the finest roots $(<1 \mathrm{~mm}$ diameter), with growth rate being closely dependent on rainfall frequency; the number of root tips was also significantly reduced during the drier months (Kummerow et al. 1982).

Excavation of the tree roots to a depth of $3 \mathrm{~m}$ showed a pronounced vertical root stratification for cocoa and Gliricidia as the fine roots of the former 
were concentrated in the $0-40 \mathrm{~cm}$ horizon, while those of the latter were more evenly distributed and reached to greater depth. The use of deuterium as a natural tracer in this stand showed that these species absorbed water from different horizons (Schwendenmann et al. 2010) as the $\delta \mathrm{D}$ signature, i.e. the deuterium to $\mathrm{H}$ ratio in the water molecules, measured for xylem sap in February 2007 suggested that water uptake by cocoa occurred primarily in the 0-30 cm horizon, whereas Gliricidia obtained most of its water from depths $>30 \mathrm{~cm}$. Despite their contrasting root architecture, no inter-specific variation in drought sensitivity was apparent and neither cocoa nor Gliricidia showed significant reductions in fine root biomass in the roof treatment. However, as only standing root biomass was examined, effects of drought on the turnover rate of fine roots cannot be excluded.

The measurements of apparent vessel embolism and water potential $\left(\Psi_{\mathrm{r}}\right)$ in the xylem of cocoa roots suggest that they remained hydraulically active throughout the desiccation period, but responded to drying soil by increasing the soil-to-root water potential gradient. The much larger decrease in $\Psi_{\mathrm{r}}$ as desiccation progressed in the roof treatment compared to control trees suggests that the roots of cocoa underwent active osmotic adjustment, which may represent an effective adaptive trait to minimize the impact of drought.

\section{Drought effects on cocoa bean yield}

While only $7-9 \%$ of the annual net primary production (NPP) of cocoa trees was invested in the production of beans (Table 3), this carbon sink appeared particularly sensitive to drought as bean yield was significantly reduced after a lag period of several months in the roof treatment, whereas leaf, stem wood, branch wood and root growth were unaffected (Fig. 8). There are reports that bean yield in cocoa is strongly affected by low rainfall (Zuidema et al. 2005) and variation in the depth of the water table (Leite and Cadima Zevallos 1991). As cocoa pods require 6-7 months to mature, the observed decline in bean yield in May/June 2008 may have resulted from reduced fruit set and ripening during the period of most intense drought between November 2007 and March 2008. Similarly, Alvim (1988) suggested that production of coffee beans may depend on rainfall distribution during the preceding six-month period. Simulations by Zuidema et al. (2005) suggested that annual radiation and rainfall during the dry season explained $70 \%$ of the variation in annual bean yield in 30 cocoa plantations throughout the tropics.

There is extensive evidence of substantial reductions in cocoa bean yield in ENSO-drought years in Sulawesi and adjacent regions of South-east Asia (Keil et al. 2008). Socio-economic studies of the consequences of ENSO-related droughts for cocoa production in Central Sulawesi revealed that bean harvests in ENSO years may be reduced to $62 \%$ relative to the normal level (Keil et al. 2008). ENSO droughts have caused the death of many cocoa trees in the area and significantly increased infestation by pests in others (N. Binternagel and H. Faust, pers. comm.). Spatial analyses of these socio-economic results suggest that the drought sensitivity of Theobroma is markedly influenced by local soil physical conditions in Central Sulawesi.

Several factors may contribute to the finding that net primary production in cocoa was generally insensitive to the 13-month drought treatment with the exception of bean production, which showed the expected decline. First, the droughted trees may have exploited water reserves that were not monitored in the study, notably the remaining throughfall water which would have added moisture to the superficial soil horizons. However, this effect would have been limited because throughfall was reduced to ca. $20 \%$ of incident rainfall and stemflow is negligible in cocoa plantations (de Miranda 1994; Dietz et al. 2006). Further, local areas of moist soil may have stimulated the trees to produce long horizontal or vertical roots to access these water reserves, as has been reported for trees growing in semi-humid climates (Hauser et al. 1993); however, such effects have rarely been examined in perhumid climates such as Central Sulawesi. Considerable effort was devoted to searching for sinker roots which might provide access to water reserves in the subsoil. Complete excavation of two cocoa and one Gliricidia tree in the core zone of each plot, mostly situated over $8 \mathrm{~m}$ from the plot border, showed that the deepest tap root of cocoa reached a depth of $1.6 \mathrm{~m}$ in a control plot, while the coarse roots of Gliricidia penetrated no deeper than $2.5 \mathrm{~m}$ (data not shown). The capture of lateral water resources is highly unlikely due to the 
large border zones around each plot, while the 'mining' of deep water reserves can be excluded for the excavated trees as none showed any reduction in aboveground productivity compared to control trees in response to the drought. Cocoa and Gliricidia therefore appear able to avoid severe desiccation despite the lack of deep or laterally extensive roots.

Second, cocoa showed a substantial decrease in root water potential during the desiccation, thereby improving root water uptake. While this decline in $\Psi_{\mathrm{r}}$ may be partly attributable to tissue dehydration, it may also suggest that cocoa can achieve significant osmotic adjustment within its roots, thereby helping to stabilise plant water status and sustain continued leaf, stem and root growth. Third, the overstorey Gliricidia trees are likely to have reduced water use by cocoa by shading its canopy (Valle et al. 1987), while competition for water was presumably limited by the spatial segregation of the root systems (Schwendenmann et al. 2010). A further possible explanation for the absence of any reduction in productivity may be that the experiment was not designed to reduce relative humidity in the stands, as happens during natural droughts. As daily mean relative humidity was ca. $80 \%$ for most of the desiccation period, an increase in atmospheric forcing of transpiration would not have occurred.

We conclude that the cocoa trees in the 6-year-old plantation shaded by Gliricidia sepium examined here showed unexpected tolerance of a 13-month experimental desiccation. Despite soil water content approaching permanent wilting point for several months in the roof treatment and the shallow fine root system of cocoa, no significant decrease in standing biomass or the productivity of leaves, stem and branch wood and roots was found relative to control trees. A possible explanation is that the permanent wilting point of cocoa trees may be lower than $-1.5 \mathrm{MPa}$, the assumed value for non-woody crops (Lösch 2001). Further possible explanations include physiological adaptations such as active osmotic adjustment in roots, mitigation of drought stress by shading from Gliricidia, complementary use of water resources, the relatively high air humidity during the soil desiccation period, or access to additional water reserves in the top soil or deep soil horizons, although our root studies do not support the latter suggestion. The economic importance of our results lies in the observation that cocoa bean yield was significantly reduced by drought, supporting earlier reports of substantial reductions in yields during ENSO-related drought events in South-east Asia.

Acknowledgements We thank LIPI, the Indonesian Research Foundation, for the research permit, the owner of the cocoa plantation, Pak Yakob and his family for permission to conduct this experiment, Thomas Klüter, Pak Andi Sofyan and their team for construction and maintenance of the desiccation roofs, Pak Umar and Maruli Sinaga for plot management and biweekly collection of stem increment and bean yield data, P. Propastin and S. Erasmi for providing LAI data, O. van Straaten and E. Veldkamp for sharing data on soil physics, and the DFG for funding the Collaborative Research Centre 552 STORMA.

Open Access This article is distributed under the terms of the Creative Commons Attribution Noncommercial License which permits any noncommercial use, distribution, and reproduction in any medium, provided the original author(s) and source are credited.

\section{References}

Alvim PT (1988) Relações entre fatores climáticos e produção do cacaueiro. In: Proceedings of 10th international cocoa research conference, Santo Domingo, Dominican Republic, pp 159-167

Beer JW (1987) Advantages, disadvantages and desirable characteristics of shade trees for coffee, cocoa and tea. Agrofor Syst 5:3-13

Bonhomme R, Chartier P (1972) The interpretation and automatic measurement of hemispherical photographs to obtain sunlit foliage. Isr J Agric Res 22:53-61

Boyd DS, Foody GM, Phipps PC (2006) Dynamics of ENSO drought events on Sabah rainforests observed by NOAA AVHRR. Int J Remote Sens 27:2197-2219

Cadima Zevallos A (1970) Estudo do sistema radicular do cacaueiro em alguns tipos de solos da regifio cacaueira da Bahia. Publicafio do Centro de Pesquisas do Cacau, Itabuna, Bahia, Brasil

de Almeida A-AF, Valle RR (2007) Ecophysiology of the cocoa tree. Braz J Plant Physiol 19:425-448

de Miranda RAC (1994) Partitioning of rainfall in a cocoa (Theobroma cacao Lour.) plantation. Hydrol Proc 8: 351-358

Dietz J, Hölscher D, Leuschner C, Hendrayanto (2006) Rainfall partitioning in relation to forest structure in differently managed montane forest stands in Central Sulawesi, Indonesia. For Ecol Manag 237:170-178

Foroughbakhch R, Alvarado-Vazquez MA, Hernandez-Pinero JL, Rocha-Estrada A, Guzman-Lucio MA, Trevino-Garza EJ (2006) Establishment, growth and biomass production of 10 woody tree species introduced for reforestation and ecological restoration in northeastern Mexico. For Ecol Manag 235:194-201

Harteveld M, Hertel D, Wiens M, Leuschner C (2007) Spatial and temporal variability of fine root abundance and 
growth in tropical moist forests and agroforestry systems (Sulawesi, Indonesia). Ecotropica 13:111-120

Hutcheon WV (1977) Growth and photosynthesis of cocoa in relation to environmental and internal factors. In: Proceedings of 5th international cocoa research conference, Ibadan, Nigeria, pp 222-232

ICCO (2007) International Cocoa Organization. Annual Report, $43 \mathrm{pp}$

Keil A, Zeller M, Wida A, Sanim B, Birner R (2008) What determines farmers' resilience towards ENSO-related drought? An empirical assessment in central Sulawesi, Indonesia. Clim Change 86:291-307

Khan MN, Patterson GR, Matlick BR (1988) Effect of supplemental water supplied through drip irrigation on cocoa yield at Lummingbird, Hershey, Ltd., Belize, C.A. In: Proceedings of 10th international cocoa research conference, Santo Domingo, Dominican Republic, pp 185-191

Kogan FN (2000) Satellite-observed sensitivity of world land ecosystems to El Nino/La Nina. Remote Sens Environ 74:445-462

Kummerow J, Kummerow A, Alvim PT (1981) Root biomass in a mature cocoa (Theobroma cacao L.) plantation. Rev Theobroma 11:77-86

Kummerow J, Kummerow M, Silva WS (1982) Fine-root growth dynamics in cocoa (T. cacao). Plant Soil 65:193201

Lang ARG, Xiang YQ (1986) Estimation of leaf area index from transmission of direct sunlight in discontinuous canopies. Agric For Meteorol 37:229-243

Leite JO, Cadima Zevallos AC (1991) Rainwater, water table and soil moisture in a hillslope. In: Proceedings of international conference on rain, water and cistern systems, Keelung, Taiwan, pp 381-386

Leite RMO, Alvim R, Alvim PT (1980) Ação do vento e da radiação solar na ruptura do pulvino foliar do cacaueiro. Rev Theobroma 104:235-251

Lösch R (2001) Wasserhaushalt der Pflanzen. UTB Quelle \& Meyer Verlag, Wiebelsheim, 595 pp

Miyaji K-I, Silva WS, Alvim PT (1997) Productivity of leaves of a tropical tree, Theobroma cacao, grown under shading, in relation to leaf age and light conditions within the canopy. New Phytol 137:463-472

Muñoz F, Beer J (2001) Fine root dynamics of shaded cocoa plantations in Costa Rica. Agrofor Syst 51:119-130

Nagai S, Ichii K, Morimoto H (2007) Interannual variations in vegetation activities and climate variability caused by ENSO in tropical rainforests. Int J Remote Sens 28:12851297

Nepstad DC, Moutinho P, Dias-Filho MB, Davidson E, Cardinot G, Markewitz D, Figueiredo R, Vianna N, Chambers J, Ray D, Buerreiros JB, Lefebvre P, Sternberg L, Moreira M, Barros L, Ishida FY, Tohlver I, Belk E, Kalif K, Schwalbe K (2002) The effects of partial throughfall exclusion on canopy processes, aboveground production, and biogeochemistry of an Amazon forest. J Geophys Res 107:1-18

Orchard JE, Saltos MR (1988) The growth and water status of cocoa during its first year of establishment under different methods of soil water management. In: Proceedings of 10th international cocoa research conference, Santo Domingo, Dominican Republic, pp 193-198
Sale PJM (1970) Growth, flowering, and fruiting of cocoa under controlled soil moisture conditions. J Hortic Sci 45:99-118

Schöngart J, Piedade MTF, Wittmann F, Junk WJ, Worbes M (2005) Wood growth patterns of Macrolobium acaciifolium (Benth.) Benth. (Fabaceae) in Amazonian blackwater and white-water floodplain forests. Oecologia 145:454-461

Schroth G, Schaller M, Jiménez F (2008) Belowground interactions in tree-crop agroforestry: Need for a new approach. In: Batish DR, Kohl RK, Jose S, Singh HP (eds) Ecological basis of agroforestry. CRC Press, London, pp 159-170

Schwendenmann L, Veldkamp E, Moser G, Hölscher D, Köhler M, Clough Y, Anas I, Djajakirana G, Erasmi S, Hertel D, Leitner D, Leuschner C, Michalzik B, Propastin P, Tjoa A, Tscharntke T, van Straaten O (2010) Effects of an experimental drought on the functioning of a cocoa agroforestry system, Sulawesi, Indonesia. Glob Change Biol 16:1515-1530

Sena Gomes AR, Kozlowski TT, Reich PB (1987) Some physiological responses of Theobroma cacao var. catongo seedlings to air humidity. New Phytol 107:591-602

Sheffield J, Wood EF (2008) Projected changes in drought occurrence under future global warming from multimodel, multi-scenario, IPCC AR4 simulations. Clim Dyn 31:79-105

Silva WS, Kummerow J (1998) Fine-root growth and longevity in a cocoa (Theobroma cacao L.) plantation. Agrotrópica 10:31-34

Smiley GL, Kroschel J (2008) Temporal change in carbon stocks of cocoa-Gliricidia agroforests in Central Sulawesi, Indonesia. Agrofor Syst 73:219-231

Sperry JS, Donnelly JR, Tyree MT (1988) A method for measuring hydraulic conductivity and embolism in xylem. Plant Cell Environ 11:35-40

Taylor SJ, Hadley P (1987) Relation between root and shoot growth in cocoa (Theobroma cacao) grown under different shade regimes. In: Proceedings of 10th international cocoa research conference, Santo Domingo, Dominican Republic, pp 77-183

Timmermann A, Oberhuber J, Bacher A, Esch M, Latif M, Roeckner E (1999) Increased El Nino frequency in a climate model forced by future greenhouse warming. Nature 398:694-697

Valle RR, Silva WS, Miranda RAC (1987) Stomatal resistance and transpiration rates of shaded and unshaded cocoa trees. Rev Theobroma 17:175-187

Veldkamp E, O'Brien JJ (2000) Calibration of a frequency domain reflectometry sensor for humid tropical soils of volcanic origin. Soil Sci Soc Am J 64:1549-1553

Willson KC (1999) Coffee, cocoa and tea. CABI Publishing, New York, p 283

Wooster MJ, Strub N (2002) Study of the 1997 Borneo fires: quantitative analysis using global area coverage (GAC) satellite data. Glob Biogeochem Cycles 16:1-12

Zuidema PA, Leffelaar PA, Gerritsma W, Mommer L, Anten NPR (2005) A physiological production model for cocoa (Theobroma cacao): model presentation, validation and application. Agric Syst 84:195-225 